\title{
PHYSICOCHEMICAL PROPERTIES OF A Ti67 ALLOY AFTER EO AND STEAM STERILIZATION
}

\author{
FIZIKALNO KEMIJSKE LASTNOSTI ZLITINE Ti67 PO EO IN \\ PARNI STERILIZACIJI
}

\author{
Witold Walke', Marcin Basiaga1, Zbigniew Paszenda ${ }^{1}$, Jan Marciniak, \\ Pawel Karasinski ${ }^{2}$
}

${ }^{1}$ Silesian University of Technology, Faculty of Biomedical Engineering, Roosevelta 40, 41-800 Zabrze, Poland ${ }^{2}$ Silesian University of Technology, Faculty of Electrical Engineering, Bolesława Krzywoustego 2, 44-100 Gliwice, Poland witold.walke@polsl.pl

Prejem rokopisa - received: 2014-09-23; sprejem za objavo - accepted for publication: 2015-05-15

doi: $10.17222 /$ mit.2014.242

The techniques of surface modification play a significant role in forming the physical and chemical properties of titanium and its alloys. Among many techniques for the layers' application, chemical and electrochemical methods are particularly interesting, as they make it possible to control the process of depositing thin layers of the material and modifying their properties through a change of reagents and the parameters of the deposition process. A special advantage the methods bring is the possibility to obtain layers that offer a perfect coating for geometrically complex surfaces. Apart from improved haemocompatibility, a significant issue related to the creation of the layers is also a proper set of physicochemical properties. Therefore, the study comprised tests of the physicochemical properties of oxide layers deposited on the surface of samples taken from a Ti-6Al-7Nb alloy. The samples were subject to various surface modifications, i.e., grinding, electrolytic polishing, a $\mathrm{SiO}_{2} \mathrm{layer}_{\mathrm{e}} \mathrm{as}_{\mathrm{applied}}$ using the sol-gel method and $\mathrm{TiO}_{2}$ by means of an anodic oxide and medical sterilisation methods (EO and steam). The corrosion-resistance tests were performed on the basis of registered anodic polarisation curves and the Stern method. Electrochemical Impedance Spectroscopy (EIS) was also used in order to evaluate the phenomena taking place on the surface of the tested alloys. As a part of the evaluation of the mechanical properties of surface layers created in such a way, hardness tests and tests of the adhesion of those layers to a metallic substrate were made. Measurements of the instrumental hardness were made with the Oliver \& Pharr method, whereas the adhesion of the layers to the substrate was measured by means of a scratch test. The suggestion of proper surface treatment variants has perspective significance and will help to develop the technological conditions with specified parameters of the oxide coating's creation on the surface of metallic implants.

Keywords: Ti-6Al-7Nb (Ti67) alloy, sol-gel, anodic oxide, scratch-test, nanohardness, EIS, potentiodynamic method

Tehnike modifikacije površine igrajo pomembno vlogo pri doseganju fizikalnih in kemijskih lastnosti titana in njegovih zlitin Med mnogimi tehnikami uporabe tankih plasti so še posebej zanimive kemijske in elektrokemijske metode, ker omogočajo kontrolo postopka depozicije tanke plasti materiala in spreminjanje njihovih lastnosti, z zamenjavo reagentov in parametrov procesa depozicije. Posebna prednost, ki jo omogočajo metode, je možnost izdelave plasti, ki omogočajo popolno prevleko pri geometrijsko kompleksnih površinah. Poleg izboljšane hemokompatibilnosti je pomembno vprašanje povezano $\mathrm{z}$ nastankom plasti in tudi $\mathrm{z}$ doseganjem ustreznih fizikalno kemijskih lastnosti. Zato je študija obsegala preizkuse fizikalno kemijskih lastnosti oksidnih plasti, po depoziciji na površini vzorcev iz Ti-6Al-7Nb zlitine. Na vzorcih so bile opravljene različne modifikacije površine: brušenje, elektrolitsko poliranje, $\mathrm{SiO}_{2}$ plast, izdelana po sol-gel postopku in $\mathrm{TiO}_{2}$ plast, izdelana $\mathrm{z}$ anodno oksidacijo in metodo medicinske sterilizacije (EO in para). Preizkusi korozijske odpornosti so bili izvršeni na osnovi zabeleženih polarizacijskih krivulj in metode Oliver \& Pharr. Za oceno pojavov na površini preizkušenih zlitin je bila uporabljena tudi elektrokemijska impedančna spektroskopija. Kot del ocene mehanskih lastnosti nastalih plasti na površini, so bile izvršene tudi meritve trdote in preizkusi oprijemljivosti plasti na kovinski podlagi. Meritve trdote so bile izvršene z metodo Oliver \& Phar, medtem ko je bila oprijemljivost izmerjena s preizkusom razenja. Predlog primernih načinov obdelave površine je pomemben, ker bo $\mathrm{v}$ prihodnje pomagal pri razvoju tehnoloških pogojev za določene parametere oksidne plasti, nastale na površini kovinskih vsadkov.

Ključne besede: Ti-6Al-7Nb (Ti67) zlitina, sol-gel, anodni oksid, preizkus razenja, nanotrdota, EIS, potenciodinamična metoda

\section{INTRODUCTION}

The haemocompatibility of titanium alloys, including the Ti-6Al-7Nb alloy, is increased by, e.g., modification of the surface layer of cardiovascular implants with surface-engineering methods. The methods used to modify the surface layers must ensure the repeatability and uniformity of their physical and chemical properties. ${ }^{1}$ The structure and chemical composition of the titanium and titanium-alloy implant layer may be modified with the use of various methods, among which the main ones are mechanical, chemical, electrochemical and thermal methods. Mechanical treatment techniques are used to modify the surface topography. The properties of the oxide layer after the application of these techniques are difficult to control. ${ }^{2}$ Chemical methods include primarily etching and passivation, which result in the formation of a thin $(<10 \mathrm{~nm})$ oxide layer composed mostly of $\mathrm{TiO}_{2}$ and oxides of the alloying elements, as well as impurities from chemical reagents. ${ }^{3-6}$ Repeatable layers with a fully controlled thickness, microstructure and chemical composition are obtained with high-temperature treatments, immersion in $\mathrm{H}_{2} \mathrm{O}_{2}$, alkaline etching, electropolishing, anodic oxidation and vacuum treatments. However, the 
method for increasing the haemocompatibility of titanium and titanium-alloy surfaces, which is increasingly often applied, involves using the sol-gel technique to produce thin oxide coatings based on $\mathrm{Si}$. The advantage of this method is the low temperature at which the coating is produced, which guarantees unchanged mechanical properties of the metal base. Moreover, this method ensures the sol's homogeneity, the possibility to regulate polycondensate molecules, a large number of metalorganic and inorganic metal salt compounds, used as precursors, as well as the possibility to obtain multiingredient coatings of high purity on different bases. ${ }^{7,8}$ Another important factor affecting the final quality of the products that come into contact with blood is the proper resistance of the modified surface to medical sterilisation. Presently, cardiovascular implants are usually sterilised with ethylene oxide (EO) and with pressurisedwater steam in an autoclave. The positive results of already-published papers by the authors regarding the assessment of the usefulness of the surface-layer modification processes involving anodic oxidation, as well as the creation of a $\mathrm{SiO}_{2}$ layer with the sol-gel method, enabled the selection of the most beneficial parameters for the process. ${ }^{1,9-11}$ An analysis of the literature data indicates that reducing the number of failed bloodsystem disease treatments depends to a large extent on the electrochemical stability of the surface layer under the medical sterilisation conditions. Therefore, this article evaluates the effects of steam and ethylene oxide sterilisation processes on the physical and chemical properties of the surface layer of the Ti-6Al-7Nb (Ti67) alloy.

\section{MATERIALS AND METHODS}

The tested material was a titanium alloy Ti-6Al-7Nb (Ti67) in the form of discs of diameter $d=14 \mathrm{~mm}$ and thickness $g=2 \mathrm{~mm}$. A number of surface-treatment methods were applied to the samples, including the following processes: grinding with the use of 1000- and 1200-grit sand paper, electrolytic polishing, the application of layers with the sol-gel technique, and anodic oxidation. The electrolytic polishing was conducted in a solution based on chromic acid z (E-395 by POLIGRAT Gmbh), with a current density $i=10-30 \mathrm{~A} / \mathrm{cm}^{2}$. The final stage of the surface treatment consisted of applying layers with two different techniques: sol-gel and anodic oxidation. In the case of the sol-gel method, a layer of $\mathrm{SiO}_{2}$ was applied with the following process parameters: $v=2.5 \mathrm{~cm} / \mathrm{min}, T=430^{\circ} \mathrm{C}, t=60 \mathrm{~min}$. The silica precursor used in the test was tetraethoxysilane $\mathrm{Si}\left(\mathrm{OC}_{2} \mathrm{H}_{5}\right)_{4}$, TEOS, and tetramethoxysilane $\mathrm{Si}\left(\mathrm{OCH}_{3}\right)_{4}$, TMOS. The remaining starting ingredients contained ethyl alcohol $(\mathrm{EtOH})$ and water. ${ }^{1,9}$ In the case of anodic oxidation a layer of $\mathrm{TiO}_{2}$ was applied in an electrolyte based on phosphoric acid and sulphuric acid (TitanColor by POLIGRAT $\mathrm{GmbH}$ ) at a potential of $90 \mathrm{~V}$. Previous studies conducted by the authors made it possible to select the most favourable parameters, both for the sol-gel technique and for the anodic oxidation. ${ }^{10,11}$

Next, the prepared samples were sterilised with ethylene oxide and steam. The sterilisation with ethylene oxide was conducted in a 12-h cycle of exposure to ethylene oxide at $30^{\circ} \mathrm{C}$. After the process was completed, the samples were ventilated for $2 \mathrm{~h}$ with the use of an EOGas series steriliser from the Andersen Products company. The sterility assurance level (SAL) obtained during the cycle was $10^{-6}$. The process was controlled with a chemical and biological indicator, as well as an indicator of exposure to the ethylene oxide control. The steam sterilisation was conducted in a Basic Plus autoclave at $T=134{ }^{\circ} \mathrm{C}$, under a pressure of $p=2.1$ bar for $t=12$ $\min$.

To evaluate the effect of ethylene oxide sterilisation and steam sterilisation on the mechanical and electrochemical properties of the proposed Ti67 surface modification, the authors suggested the following tests of the mechanical properties: measurements of the adhesion of the analysed layers to the base and their hardness. Electrochemical tests included potentiodynamic and impedance measurements.

First, as part of the mechanical properties' tests, the measurement of a layer's adhesion to the base was performed using the scratching method, with the use of an open platform equipped with a Micro-Combi-Tester from the CSM company, in accordance with the standard. ${ }^{12}$ The test consisted of making a scratch using a penetrator - a Rockwell diamond cone - with a gradually increasing normal force weighting the penetrator. To assess the value of the critical force $L c$, records of variations in the acoustic emission signals, the friction force and the friction coefficient were used, as well as a microscopic observation with the use of an optical microscope, and an integral component of the platform. The tests were performed with an increasing weighting force of $0.03-20 \mathrm{~N}$, and with the following parameters: weighting speed $10 \mathrm{~N} / \mathrm{min}$, table movement speed 1.5 $\mathrm{mm} / \mathrm{min}$, and length of the scratch $\sim 3 \mathrm{~mm}$.

Later, measurements of the nanohardness of the layers applied with the sol-gel method, and with the anodic oxidation method, were conducted. The instrumental hardness measurement was performed with the Oliver and Pharr method, using a Berkovich penetrator. The speed of the increasing weighting and relieving force was $0.40 \mathrm{mN} / \mathrm{min}$. The measurement of the layer's nanohardness was made with the Micro-Combi-Tester open platform from the CSM Instruments company, where the weighting force of the penetrator was 0.20 $\mathrm{mN} .^{13}$

Subsequently, as part of the electrochemical properties testing, the resistance to pitting erosion was tested with the potentiodynamic method, recording the polarisation curves. They were used as a base to determine the values of specific parameters: the corrosion potential 
$E_{\text {corr }}(V)$ and the polarisation potential $R_{\mathrm{p}}\left(\Omega \mathrm{cm}^{2}\right)$. At the beginning of the testing, the value of the opening potential $E_{\mathrm{OCP}}$ was determined without any electric current. Then, the anode polarisation curves were recorded. The measurements started for the potential of $E_{\mathrm{start}}=E_{\mathrm{OCP}}-$ $100 \mathrm{mV}$, and the change of potential in the anodic direction was at a speed of $0.16 \mathrm{mV} / \mathrm{s}$, until the anodic current density reached a value of $i=1 \mathrm{~mA} / \mathrm{cm}^{2}$, or the measurement range of $4 \mathrm{~V}$ was reached. ${ }^{14}$

As part of the EIS testing, the impedance spectra of the analysed corrosive systems were determined, and then the obtained measurement data were adjusted to the corresponding substitute systems. The impedance spectra of the systems tested are presented on Nyquist diagrams for the different frequencies as well as on Bode diagrams. Also, the numerical values of the resistance $R$ were established, as well as the capacities $C$ of the analysed corrosive systems. The resulting spectra were interpreted after being adjusted with the least-squares method to the substitute electric systems. Based on the results obtained, it was possible to characterise the impedance of the phase boundaries, i.e., Ti-6Al-7Nb (Ti67) surface layer - blood plasma, with an approximation of the impedance data using an electric model of a substitute circuit. The testing environment was an artificial blood-plasma solution of $T=37 \pm 1{ }^{\circ} \mathrm{C}$. The measurements were performed using the AutoLab PGSTAT 302N measurement system, equipped with a FRA2 (Frequency Response Analyser) module. The reference electrode was a saturated calomel electrode SCE, type KP-113, whereas the supporting electrode was a platinum electrode type PtP-201. The system used made it possible to conduct tests within the frequency range $10^{4}$ to $10^{-3} \mathrm{~Hz}$. The voltage amplitude of the sinusoid stimulating signal was $10 \mathrm{mV} \cdot{ }^{15,16}$

Table 1: The results of the adhesion of the layer on the Ti67 substrate Tabela 1: Oprijemljivost plasti na podlagi iz Ti67

\begin{tabular}{|c|c|c|c|c|c|c|c|}
\hline & \multirow{3}{*}{ Failure of the layer } & \multicolumn{6}{|c|}{ The value of registered indenter load $F_{\mathrm{n}}, \mathrm{N}$} \\
\hline & & \multicolumn{3}{|c|}{$\mathrm{Ti} 67+\mathrm{SiO}_{2}$} & \multicolumn{3}{|c|}{$\mathrm{Ti} 67+\mathrm{TiO}_{2}$} \\
\hline & & inital state & steam & $\mathrm{EO}$ & inital state & steam & $\mathrm{EO}$ \\
\hline \multirow{2}{*}{$\begin{array}{l}\text { Measure- } \\
\text { ment } 1\end{array}$} & Delamination $L \mathrm{c}_{1}$ & 2.01 & 1.57 & 1.54 & 6.64 & 2.98 & 3.14 \\
\hline & Complete break $L c_{2}$ & 3.57 & 2.24 & 3.21 & 8.01 & 6.54 & 5.03 \\
\hline \multirow{2}{*}{$\begin{array}{l}\text { Measure- } \\
\text { ment } 2\end{array}$} & Delamination $L c_{1}$ & 2.48 & 1.33 & 1.89 & 3.06 & 3.14 & 2.36 \\
\hline & Complete break $L c_{2}$ & 3.89 & 2.45 & 3.22 & 6.88 & 6.18 & 4.27 \\
\hline \multirow{2}{*}{$\begin{array}{l}\text { Measure- } \\
\text { ment } 3\end{array}$} & Delamination $L c_{1}$ & 3.55 & 1.41 & 2.41 & 4.33 & 3.52 & 2.86 \\
\hline & Complete break $L c_{2}$ & 5.02 & 2.12 & 4.31 & 7.37 & 6.88 & 4.81 \\
\hline \multirow{2}{*}{ Average } & Delamination $L \mathrm{c}_{1}$ & 2.68 & 1.43 & 1.94 & 4.67 & 3.21 & 2.78 \\
\hline & Complete break $L c_{2}$ & 4.16 & 2.27 & 3.58 & 7.42 & 6.53 & 4.70 \\
\hline \multirow{2}{*}{$\begin{array}{l}\text { Standard } \\
\text { deviation }\end{array}$} & Delamination $L c_{1}$ & \pm 0.78 & \pm 0.12 & \pm 0.43 & \pm 1.81 & \pm 0.59 & \pm 0.39 \\
\hline & Complete break $L c_{2}$ & \pm 0.76 & \pm 0.16 & \pm 0.63 & \pm 0.56 & \pm 0.35 & \pm 0.39 \\
\hline
\end{tabular}

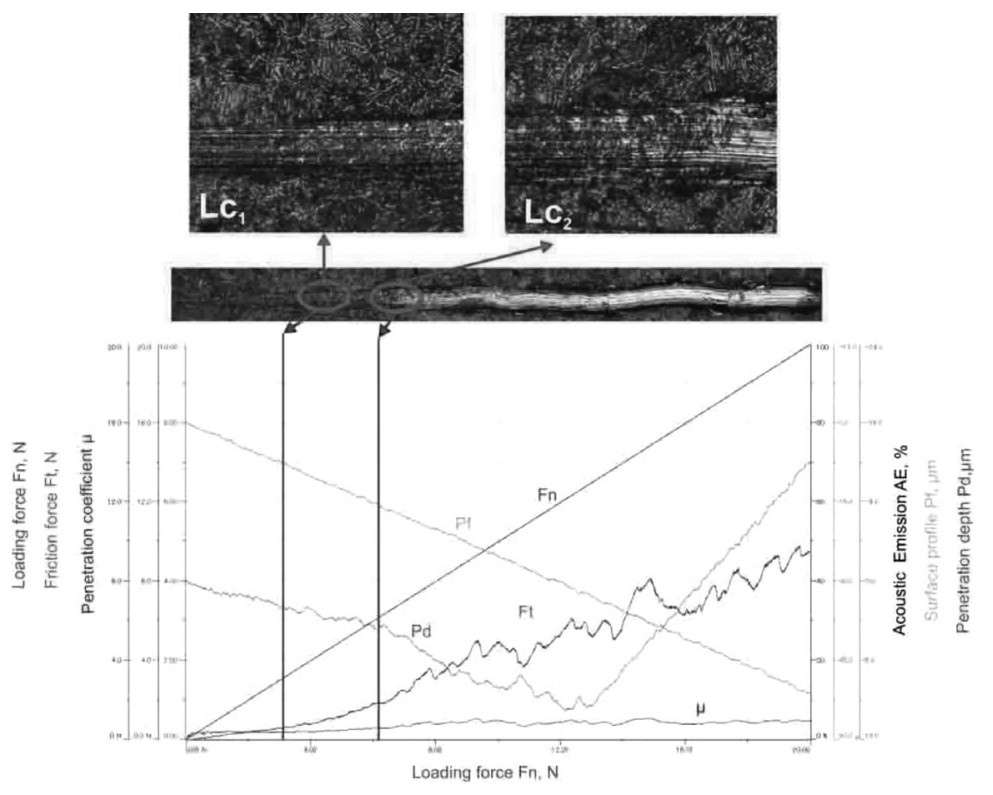

Figure 1: Results of the adhesion tests of the sample $\mathrm{Ti}^{6}+\mathrm{TiO}_{2}$ (steam)

Slika 1: Rezultati preizkusov oprijemljivosti vzorca $\mathrm{Ti}_{67}+\mathrm{TiO}_{2}$ (para) 


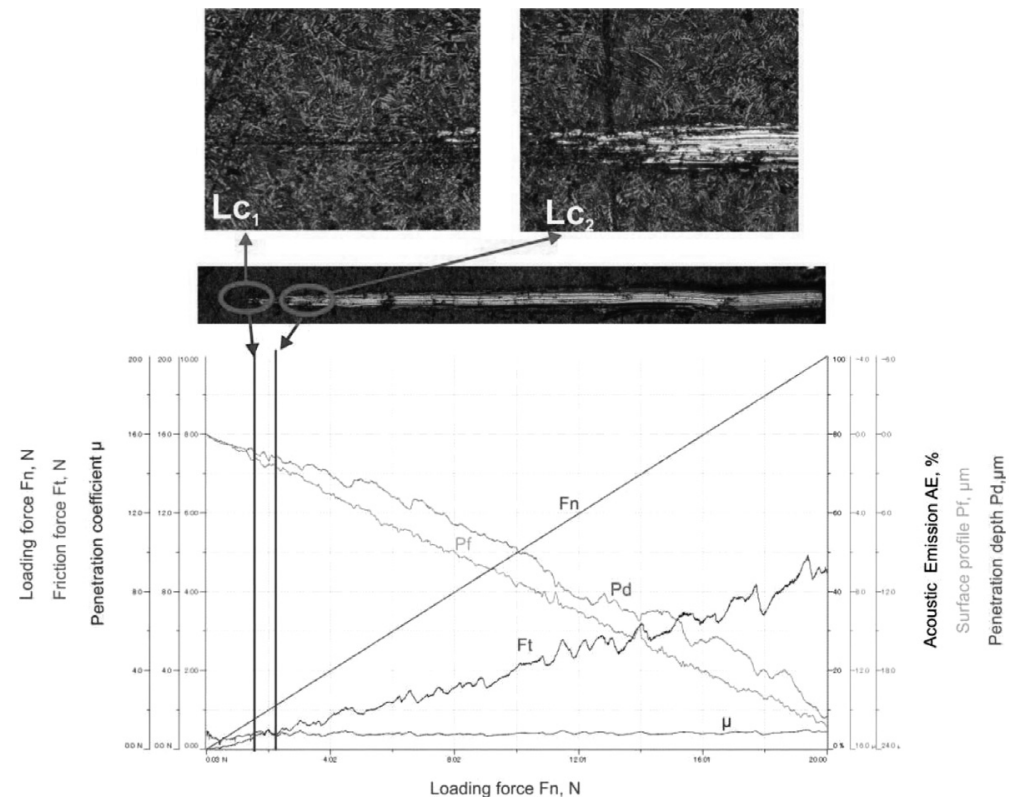

Figure 2: Results of the adhesion tests of the sample $\mathrm{Ti}_{67}+\mathrm{SiO}_{2}$ (steam) Slika 2: Rezultati preizkusov oprijemljivosti vzorca $\mathrm{Ti} 67+\mathrm{SiO}_{2}$ (para)

\section{RESULTS AND DISSCUSION}

The test results for the adhesion of the analysed layers to the base made of Ti-6Al-7Nb (Ti67) alloy are presented in Table 1, Figures $\mathbf{1}$ and $\mathbf{2}$. It was found that in the case of samples in the initial state the critical value that caused the layer delamination, the external and the internal delamination, was $L \mathrm{c}_{2}=4.16 \mathrm{~N}-\mathrm{Ti}^{6} 7+\mathrm{SiO}_{2}$ and $L \mathrm{c}_{2}=7.42 \mathrm{~N}-\mathrm{Ti}_{67}+\mathrm{TiO}_{2}$. While using both steam and ethylene oxide sterilisation, the critical force value was reduced and for $\mathrm{Ti} 67+\mathrm{SiO}_{2}$ it was $L \mathrm{c}_{2}=2.27 \mathrm{~N}$ (steam), $L \mathrm{c}_{2}=3.58 \mathrm{~N}(\mathrm{EO})$, whereas for $\mathrm{Ti} 67+\mathrm{TiO}_{2}$ it was $L \mathrm{c}_{2}=$ $6.53 \mathrm{~N}$ (steam), $L \mathrm{c}_{2}=4.70 \mathrm{~N}$ (EO). Regardless of the analysed sample type, an acoustic emission signal did not occur during the test, which indicates that the binding energy between the coating and the base was too low. Moreover, no significant differences between using

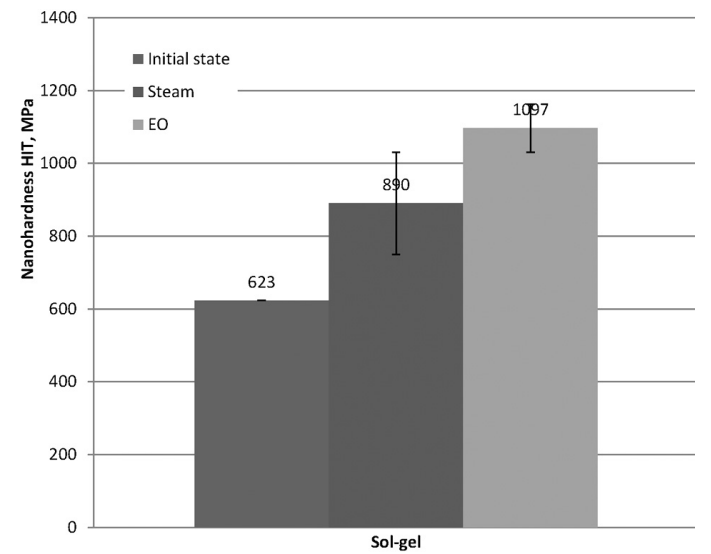

Figure 3: Results of the nanohardness tests of the sample $\mathrm{Ti} 67+\mathrm{SiO}_{2}$ Slika 3: Nanotrdota vzorca $\mathrm{Ti} 67+\mathrm{SiO}_{2}$ steam sterilisation or ethylene oxide sterilisation were found.

Furthermore, the hardness of the analysed layers was tested. The test results are presented in Figures 3 and 4. On the basis of the results obtained, an increase in the hardness value following the steam sterilisation, as well as the ethylene oxide sterilisation, compared to the initial state was observed. The polarisation curves determined for the samples with a $\mathrm{Ti} 67\left(\mathrm{TiO}_{2}\right)$ layer are presented in Figure 5, and for the samples with a $\mathrm{Ti67}\left(\mathrm{SiO}_{2}\right)$ layer in Figure 6.

Regardless of the surface-preparation method or the sterilisation technique, a hysteresis loop was not present in the anodic range up to $4 \mathrm{~V}$, which is a positive phenomenon, indicating the absence of pitting erosion. The determined values of the corrosive potential $E_{\text {corr }}$ and the polarisation resistance $R_{p}$ for the individual variant of the samples tested were as follows: $\mathrm{Ti} 67+\mathrm{TiO}_{2}-E_{\text {corr }}=-112 \mathrm{mV}$,

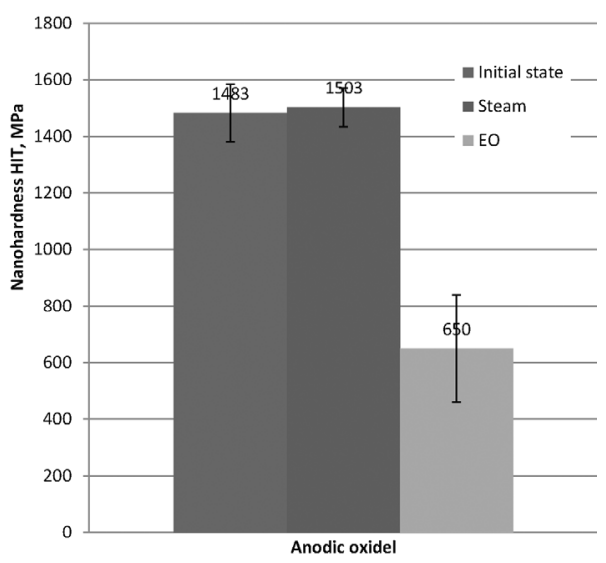

Figure 4: Results of the nanohardness tests of the sample $\mathrm{Ti}_{167}+\mathrm{TiO}_{2}$ Slika 4: Nanotrdota vzorca Ti67+TiO 2 


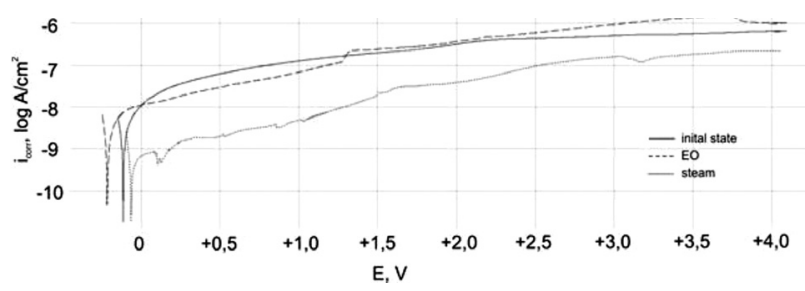

Figure 5: Anodic polarisation curves of $\mathrm{Ti}_{7}+\mathrm{TiO}_{2}$

Slika 5: Krivulje anodne polarizacije $\mathrm{Ti67}+\mathrm{TiO}_{2}$

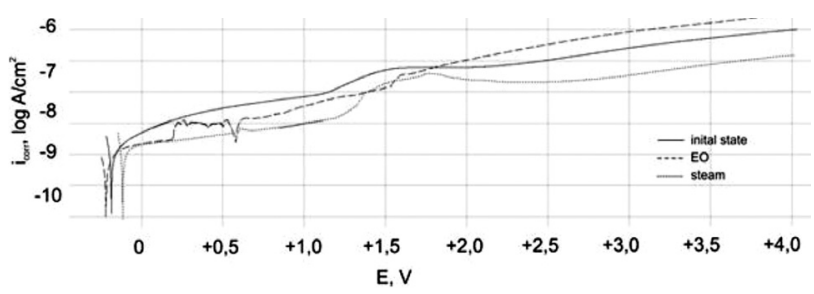

Figure 6: Anodic polarisation curves of $\mathrm{Ti} 67+\mathrm{SiO}_{2}$

Slika 6: Krivulje anodne polatizacije $\mathrm{Ti} 67+\mathrm{SiO}_{2}$

$R_{\mathrm{p}}=7480 \mathrm{k} \Omega \mathrm{cm}^{2} ; \mathrm{Ti}_{67}+\mathrm{TiO}_{2}($ steam $)-E_{\text {corr }}=-67 \mathrm{mV}$, $R_{\mathrm{p}}=3340 \mathrm{k} \Omega \mathrm{cm}^{2} ; \mathrm{Ti}_{67}+\mathrm{TiO}_{2}(\mathrm{EO})-E_{\text {corr }}=-217 \mathrm{mV}$, $R_{\mathrm{p}}=8340 \mathrm{k} \Omega \mathrm{cm}^{2} ; \mathrm{Ti} 67+\mathrm{SiO}_{2}-E_{\text {corr }}=-108 \mathrm{mV}, R_{\mathrm{p}}=$ $1460 \mathrm{k} \Omega \mathrm{cm}^{2} ; \mathrm{Ti} 67+\mathrm{SiO}_{2}$ (steam) $-E_{\text {corr }}=-118 \mathrm{mV}, R_{\mathrm{p}}=$ $1850 \mathrm{k} \Omega \mathrm{cm}^{2} ; \mathrm{Ti} 67+\mathrm{SiO}_{2}(\mathrm{EO})-E_{\text {corr }}=-219 \mathrm{mV}, R_{\mathrm{p}}=$ $4290 \mathrm{k} \Omega \mathrm{cm}^{2}$, respectively. Figures 7 and 8 present the impedance spectra recorded for the samples before and after the sterilisation process for different variants of the surface preparation. To analyse the experimentally determined impedance spectra for the corrosive system of $\mathrm{Ti} 67+\mathrm{SiO}_{2}, \mathrm{Ti} 67+\mathrm{SiO}_{2}$ (steam), $\mathrm{Ti} 67+\mathrm{SiO}_{2}$ (EO), a substitute electric system was used, which indicates the presence of a double layer (two time invariables visible in the diagram), where $R s$ signifies the electrolyte resistance, $R_{p}$ is the electrolyte resistance in pores, and $C P E_{\mathrm{p}}$ is the capacity of the double layer (porous layer, surface layer), while $R_{\mathrm{ct}}$ and $C P E_{\mathrm{dl}}$ are the resistance and capacity of the oxide layer. Using two constant phase elements in the electric substitute circuit had an advantageous effect on the quality of the adjustment of the experimentally determined curves (Figure 9a and Table 2).

Table 2: EIS analysis results

Tabela 2: Rezultati EIS-analize

\begin{tabular}{|c|c|c|c|c|c|c|c|c|c|c|c|}
\hline \multirow[b]{2}{*}{ Surface } & \multirow{2}{*}{$\begin{array}{c}R_{\mathrm{s}}, \\
\Omega \mathrm{cm}^{2}\end{array}$} & \multirow{2}{*}{$\begin{array}{c}R_{\text {pore }} \\
\Omega \mathrm{cm}^{2}\end{array}$} & \multicolumn{2}{|c|}{$C P E_{\text {pore }}$} & \multirow[b]{2}{*}{$\begin{array}{c}R_{\mathrm{p}} \\
\mathrm{k} \Omega \mathrm{cm}^{2}\end{array}$} & \multicolumn{2}{|c|}{$C P E_{\mathrm{p}}$} & \multirow[b]{2}{*}{$\begin{array}{c}R_{\mathrm{ct}} \\
\mathrm{M} \Omega \mathrm{cm}^{2}\end{array}$} & \multicolumn{2}{|c|}{$C P E_{\mathrm{dl}}$} & \multirow{2}{*}{$\begin{array}{c}W \\
\mu \Omega \mathrm{cm}^{2}\end{array}$} \\
\hline & & & $\begin{array}{c}Y_{0} \\
\Omega^{-1} \mathrm{~cm}^{-2} \mathrm{~s}^{-\mathrm{n}}\end{array}$ & $n$ & & $\begin{array}{c}\mathrm{Y}_{0} \\
\Omega^{-1} \mathrm{~cm}^{-2} \mathrm{~s}^{-\mathrm{n}}\end{array}$ & $n$ & & $\begin{array}{c}\mathrm{Y}_{0} \\
\Omega^{-1} \mathrm{~cm}^{-2} \mathrm{~s}^{-\mathrm{n}}\end{array}$ & $n$ & \\
\hline \multicolumn{12}{|c|}{$\mathrm{Ti67}\left(\mathrm{TiO}_{2}\right)$} \\
\hline inital state & 17 & - & - & - & 68 & $0,3580 \mathrm{E}-4$ & 0,92 & 25,00 & $0,2306 \mathrm{E}-4$ & 0,90 & 3 \\
\hline $\mathrm{EO}$ & 18 & 54 & $0,5407 \mathrm{E}-6$ & 0,93 & 1830 & $0,6381 \mathrm{E}-6$ & 0,83 & 20,88 & $0,1455 \mathrm{E}-5$ & 0,81 & - \\
\hline steam & 17 & - & - & - & 42 & $0,2534 \mathrm{E}-6$ & 0,96 & 0,96 & $0,2504 \mathrm{E}-6$ & 0,90 & 35 \\
\hline \multicolumn{12}{|c|}{$\mathrm{Ti67}\left(\mathrm{SiO}_{2}\right)$} \\
\hline inital state & 17 & & & & 53 & $0,9823 \mathrm{E}-5$ & 0,98 & 9,44 & $0,5294 \mathrm{E}-5$ & 0,93 & - \\
\hline $\mathrm{EO}$ & 18 & - & - & - & 52 & $0,7975 \mathrm{E}-5$ & 0,92 & 11,87 & $0,1068 \mathrm{E}-4$ & 0,87 & - \\
\hline steam & 18 & - & - & - & 87 & $0,1213 \mathrm{E}-4$ & 0,89 & 4,84 & $0,1524 \mathrm{E}-6$ & 0,96 & - \\
\hline
\end{tabular}
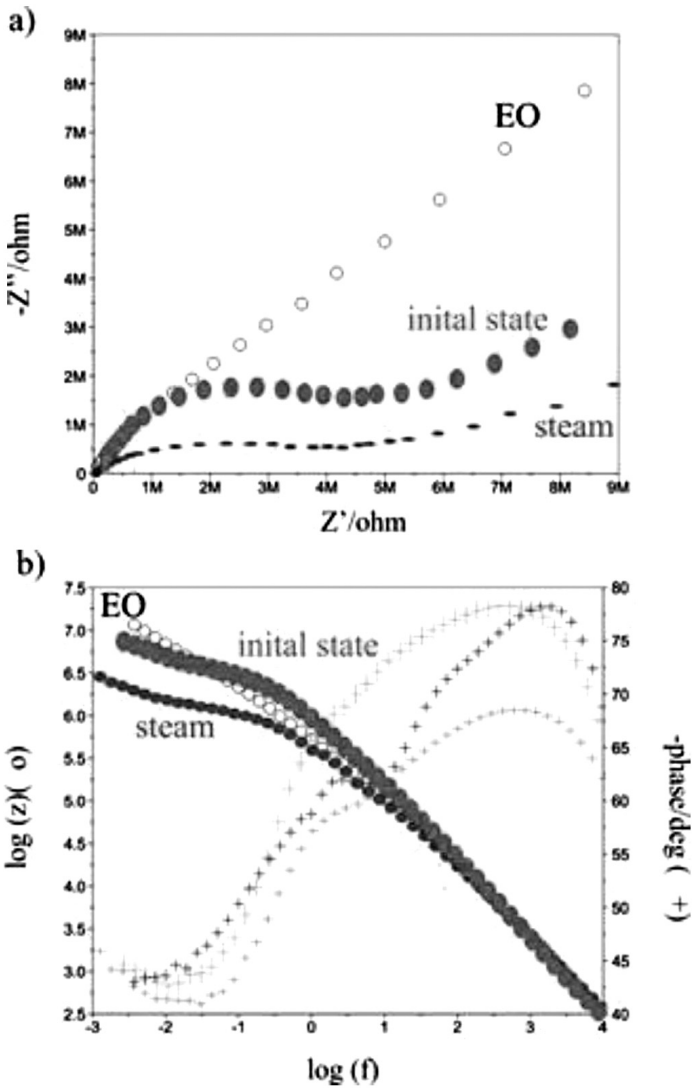

Figure 7: Impedance spectra for the sample $\mathrm{Ti} 67+\mathrm{SiO}_{2}$ : a) Nyquist plot, b) Bode diagram

Slika 7: Impedančni spekter vzorca $\mathrm{Ti} 67+\mathrm{SiO}_{2}$ : a) diagram Nyquist, b) diagram Bode

The impedance spectra obtained for the $\mathrm{Ti}_{67}+\mathrm{TiO}_{2}$ and $\mathrm{Ti}_{67}+\mathrm{TiO}_{2}$ (steam) samples were interpreted by comparing them to the substitute electric system, which indicates the presence of an anodic layer composed of two sublayers: ${ }^{9-11}$ a compact internal layer and a porous external one, composed primarily of titanium oxide $\mathrm{TiO}_{2}$ (Figure 9b). It is indicated by the presence of the Warburg impedance, which in this case represents probable oxygen transport to the alloy surface. In addition, the $C P E_{p}$ element models the capacity of the surface material sphere with a significant surface extension, while $R_{p}$ 
a)

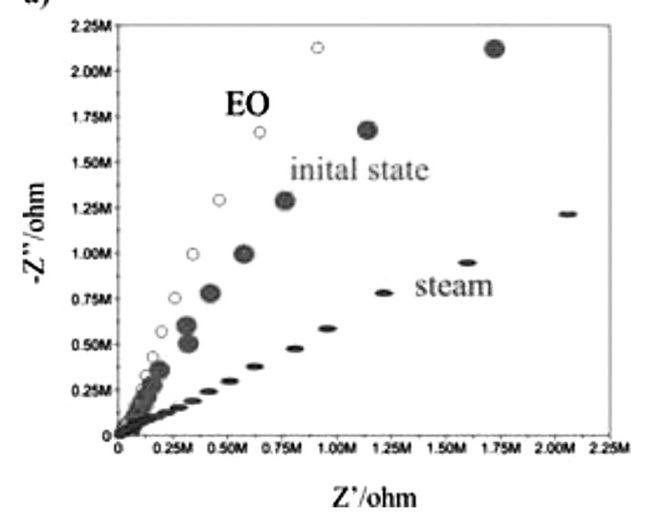

b)

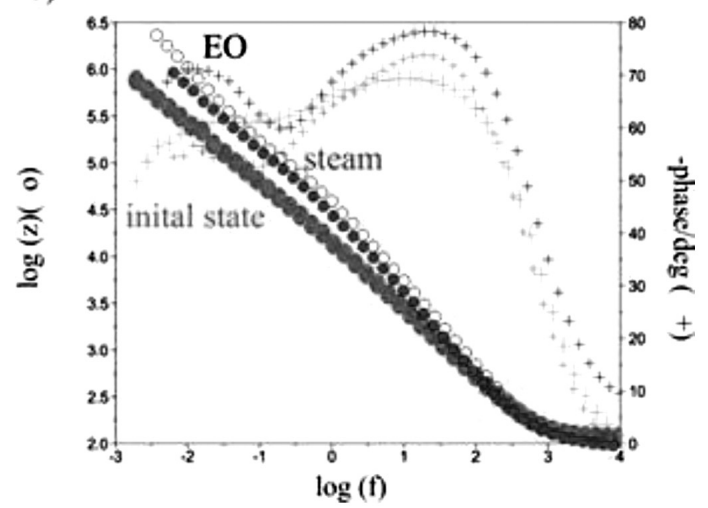

Figure 8: Impedance spectra for the sample $\mathrm{Ti} 67+\mathrm{TiO}_{2}$ : a) Nyquist plot, b) Bode diagram

Slika 8: Impedančni spekter vzorca $\mathrm{Ti}_{67}+\mathrm{TiO}_{2}$ : a) diagram Nyquist, b) diagram Bode

a)
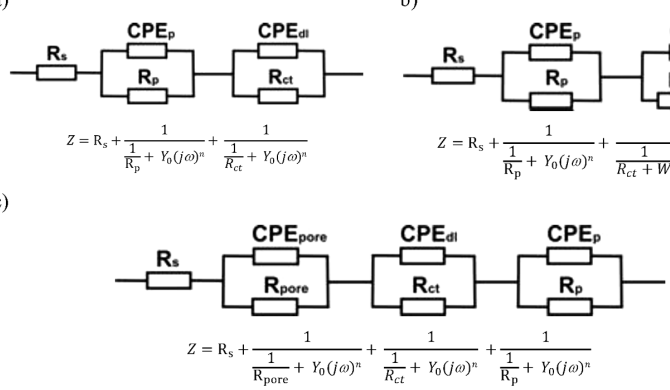

Figure 9: Physical models of an electrical equivalent system of the corrosion system metal - solution ${ }^{9-11}$

Slika 9: Fizikalni model električnega ekvivalentnega sistema korozijskega sistema kovina-raztopina ${ }^{9-11}$

reflects the electrolyte resistance in this sphere of the material (Table 2).

The impedance spectra obtained for the $\mathrm{Ti} 67+\mathrm{TiO}_{2}$ (EO) sample were adjusted to the substitute system, which indicates the presence of three time invariables (Figure 9c). The symbols in Figure 9c signify the following: $C P E_{\text {pore }}$ - capacity of the surface sphere of the material with a high level of surface extension (porous), $R_{\text {pore }}$ - electrolyte resistance in pores, $C P E_{\mathrm{dl}}$ - capacity of the double layer, $R_{\mathrm{ct}}$ - charge-transfer resistance at the phase boundary (it characterises the speed of the corro- sive process), $C_{\mathrm{dl}}-$ capacity of the double layer, $C P E_{\mathrm{P}}-$ capacity of the passive layer (oxide), $R_{\mathrm{P}}$ - passive (oxide) layer resistance (Table 2). ${ }^{9-11}$

\section{CONCLUSIONS}

An important problem in the process of modelling the performance properties of the implants used in cardiology is the proper selection of the physical and chemical characteristics of their surface. The physicochemical properties of the implant surface should be adjusted to the characteristics of the human tissue environment - in this case, to the blood environment. The safety of the device's use is also associated with the need to follow the proper procedures preventing the transfer of pathogenic microorganisms into the human organism. The aim of these procedures is to remove and effectively destroy the microorganisms, i.e., to obtain sterile devices that meet the quality requirements defined in the standards. For medical devices that come into contact with blood, sterilisation with ethylene oxide or pressurised-water steam are the most frequently used. Therefore, accounting for the effect of these sterilisation processes on the properties of the analysed surface layer will enable their complete characterisation. ${ }^{17}$

The conducted impedance tests revealed that on the surface of the Ti-6Al-7Nb alloy, modified through anodic oxidation, a porous layer $\left(\mathrm{TiO}_{2}\right)$ is found, in which parallel channels with an ionic conduction are formed. It is a layer that forms as a result of diffusion processes, which is indicated by the presence of the Warburg impedance. These processes intensify during the activity of pressurised-water steam in the sterilisation process. As a consequence, it leads to the partial dissolution of $\mathrm{TiO}_{2}$, as indicated by the lower value of the ionic transfer resistance $R_{\mathrm{ct}}$. Sterilisation with ethylene oxide positively increases the $R_{\mathrm{ct}}$ value. This phenomenon may be caused by the increased oxygen concentration near the surface during the process, and the formation of an additional oxide layer. Diffusion processes associated with the partial dissolution of oxide in the solution were not observed in the samples with an applied $\mathrm{SiO}_{2}$ layer. This layer appears to be more compact than the $\mathrm{TiO}_{2}$. Regardless of the sterilisation method used, no changes in the properties of the layer were found. Only, as was the case with the samples undergoing anodic oxidation, a reduction in the ion-transfer resistance $\mathrm{R}_{\mathrm{ct}}$ was observed. The conducted tests for layer adhesion to the base revealed a slight reduction in the adhesive force of the sterilised layers versus the samples in the initial state. The tests demonstrated the better adhesion of $\mathrm{TiO}_{2}$ than $\mathrm{SiO}_{2}$ to the Ti-6Al-7Nb alloy base. The hardness testing conducted in the study revealed that pressurised steam does not cause significant changes to the hardness of the $\mathrm{TiO}_{2}$ or $\mathrm{SiO}_{2}$, whereas sterilisation with ethylene oxide results in an increased hardness of the $\mathrm{SiO}_{2}$ and a significant reduction in the hardness of the $\mathrm{TiO}_{2}$. This phenomenon 
may cause increased porosity of the $\mathrm{TiO}_{2}$ layer, resulting from the effect of ethylene oxide, as demonstrated in the EIS tests. The $\mathrm{SiO}_{2}$ layer also reacts when in contact with ethylene oxide. Its hardness significantly increases, which may be the cause of the formation on its surface of an additional oxide layer, based on $\mathrm{Ti}$ and $\mathrm{Si}$, revealing better mechanical properties. To sum up, the conducted study of the modified surfaces of the Ti-6Al-7Nb alloy samples with the $\mathrm{TiO}_{2}$ and $\mathrm{SiO}_{2}$ layers demonstrated that the medical sterilisation process affects the physical and chemical properties of these layers. The selection of the proper surface layers should also depend on the manner and the method of sterilisation.

\section{Acknowledgements}

The project was funded by the National Science Centre, allocated on the basis of decision No. 2011/03/ B/ST8/06499.

\section{REFERENCES}

${ }^{1}$ W. Walke, Z. Paszenda, M. Basiaga, P. Karasiński, M. Kaczmarek, EIS study of $\mathrm{SiO}_{2}$ oxide film on 316L stainless steel for cardiac implants. Information Technologies in Biomedicine, 4, Advances in Intelligent Systems and Computing, 284 (2014), 403-410 doi:10.1007/978-3-319-06596-0_38

${ }^{2}$ N. Ibris, J. C. M. Rosca, EIS study of Ti and its alloys in biological media, Journal of Electroanalytical Chemistry, 526 (2002), 53-62, doi:10.1016/S0022-0728(02)00814-8

${ }^{3}$ J. Y. Park, J. E. Davies, Red blood cell and platelet interactions with titanium implant surfaces, Clinical Oral Implants Research, 11 (2000) 6, 530-539, doi:10.1034/j.1600-0501.2000.011006530.x

${ }^{4}$ J. E. Ellingsen, Pre-treatment of titanium implants with fluoride improves their retention in bone, Biomaterials, 12 (1991) 6, 593-596, doi:10.1016/ 0142-9612(91)90057-H

${ }^{5}$ M. Basiaga, Z. Paszenda, A. Kajzer, The effect of EO and steam sterilization on mechanical and electrochemical properties of titanium Grade 4, Mater. Tehnol., 50 (2016) 1, 153-158 doi:10.17222/mit. 2014.241
${ }^{6}$ C. Sitting, G. Hahner, A. Marti, M. Textor, N. D. Spencer, R. Hauert, Mechanoelectrochemical synthesis of porous Ti-based nanocomposite biomaterials, Journal of Materials Science: Materials in Medicine, 10 (1999), 191-198

${ }^{7}$ S. Shibli, S. Mathai, The role of calcium gluconate in electrochemical activation of titanium for biomimetic coating of calcium phosphate, J. Mat. Sci., 19 (2008), 2971-2981

${ }^{8}$ P. Karasiński, J. Jaglarz, M. Reben, E. Skoczek, J. Mazur, Porous silica xerogel films as antireflective coatings. Fabrication and characterization, Optical Materials, 33 (2011), 1989-1994

${ }^{9}$ M. Basiaga, Z. Paszenda, W. Walke, P. Karasiński, J. Marciniak, Electrochemical impedance spectroscopy and corrosion resistance of $\mathrm{SiO}_{2}$ coated cpTi and Ti-6Al-7Nb alloy, Information Technologies in Biomedicine, 284 (2014), 411-420, doi:10.1007/978-3-319-065960_39

${ }^{10}$ W. Walke, M. Basiaga, Z. Paszenda, Tests of mechanical properties of SiO2 layers for implants used in vascular system, Engineering of Biomaterials, 124 (2014), 36-41

${ }^{11}$ A. Kajzer, W. Kajzer, J. Dzielicki, D. Matejczyk, The study of physicochemical properties of stabilizing plates removed from the body after treatment of pectus excavatum. Acta of Bioengineering and Biomechanics, 2 (2015), 35-44 doi:10.5277/ABB-00140-2014-02

${ }^{12}$ J. von Stebut, Multi-mode scratch testing - a European standards, measurements and testing study, Surface and Coatings Technology, 200 (2005), 346-350, doi:10.1016/j.surfcoat.2005.02.055

${ }^{13}$ EN ISO 14577-1 Metallic materials-Instrumented indentation test for hardness and materials parameters-Part1: Test method

${ }^{14}$ ASTM F2129-08 Standard Test Method for Conducting Cyclic Potentiodynamic Polarization Measurements to Determine the Corrosion Susceptibility of Small Implant Devices

${ }^{15}$ M. Kaczmarek, W. Walke, Z. Paszenda, Application of electrochemical impedance spectroscopy in evaluation of corrosion resistance of Ni-Ti alloy, Electrical Review, 12b (2011), 74-78

${ }^{16}$ M. Kiel-Jamrozik, J. Szewczenko, W. Walke, J. Marciniak, Zastosowanie EIS do oceny własności fizykochemicznych modyfikowanego powierzchniowo stopu Ti-6Al-4V ELI, Electrical Review, 12b (2012), 232-235

${ }^{17}$ W. Walke, J. Przondziono, J. Szade, Electrochemical and XPS studies of AISI 316L after Development of warm forging method for magnesium alloyEuropean Cells and Materials, 26 (2013) 6, 117 